\title{
Monte Carlo Simulations of Atom Transfer Radical (Homo)polymerization of Divinyl Monomers: Applicability of Flory-Stockmayer Theory
}

Lyu, Jing; Zhang, Zidang; Greiser, Udo; Polanowski, Piotr; Jeszka, Jeremiasz K; Matyjaszewski, Krzysztof; Tai, Hongyun; Wang, Wenxin

\section{Macromolecules}

DOI:

10.1021/acs.macromol.8b01630

Published: 11/09/2018

Peer reviewed version

Cyswllt i'r cyhoeddiad / Link to publication

Dyfyniad o'r fersiwn a gyhoeddwyd / Citation for published version (APA):

Lyu, J., Zhang, Z., Greiser, U., Polanowski, P., Jeszka, J. K., Matyjaszewski, K., Tai, H., \& Wang, W. (2018). Monte Carlo Simulations of Atom Transfer Radical (Homo)polymerization of Divinyl Monomers: Applicability of Flory-Stockmayer Theory. Macromolecules, 51(17), 66736681. https://doi.org/10.1021/acs.macromol.8b01630

Hawliau Cyffredinol / General rights

Copyright and moral rights for the publications made accessible in the public portal are retained by the authors and/or other copyright owners and it is a condition of accessing publications that users recognise and abide by the legal requirements associated with these rights.

- Users may download and print one copy of any publication from the public portal for the purpose of private study or research.

- You may not further distribute the material or use it for any profit-making activity or commercial gain

- You may freely distribute the URL identifying the publication in the public portal ?

Take down policy

If you believe that this document breaches copyright please contact us providing details, and we will remove access to the work immediately and investigate your claim. 
Supporting Information:

\section{Monte Carlo Simulations of Atom Transfer Radical (Homo)Polymerization of Divinyl Monomers: Applicability of Flory-Stockmayer Theory}

Jing Lyu, ${ }^{\dagger}$, Yongsheng Gao, $^{\dagger}$ Zidan Zhang, ${ }^{\S}$ Udo Greiser, ${ }^{\dagger}$ Piotr Polanowski, ${ }^{\#}$ Jeremiasz K. Jeszka, ${ }^{\%}$ Krzysztof Matyjaszewski,॥ Hongyun $\mathrm{Tai}^{\perp}$ and Wenxin Wang ${ }^{*}, \dagger, *$

${ }^{\dagger}$ Charles Institute of Dermatology, School of Medicine, University College Dublin, Belfield, Dublin 4, Ireland

${ }^{\ddagger}$ School of Mechanical and Materials Engineering, University College Dublin, Dublin 4, Ireland

$\S^{\S}$ Division of Polymer Chemistry and Materials, Department of Chemistry, Katholieke Universiteit Leuven, Celestijnenlaan 200F, B-3001 Heverlee, Belgium

\#Department of Molecular Physics, Technical University of Lodz, 90-924, Lodz, Poland

${ }^{\%}$ Department of Man-Made Fibres, Technical University of Lodz, 90-924, Lodz, Poland

॥Center for Macromolecular Engineering, Department of Chemistry, Carnegie Mellon University, Pittsburgh, Pennsylvania 15213, USA

${ }^{\perp}$ School of Chemistry, Bangor University, Deiniol Road, Bangor, Gwynedd, LL57 2UW, UK

E-mail: wenxin.wang@ucd.ie 

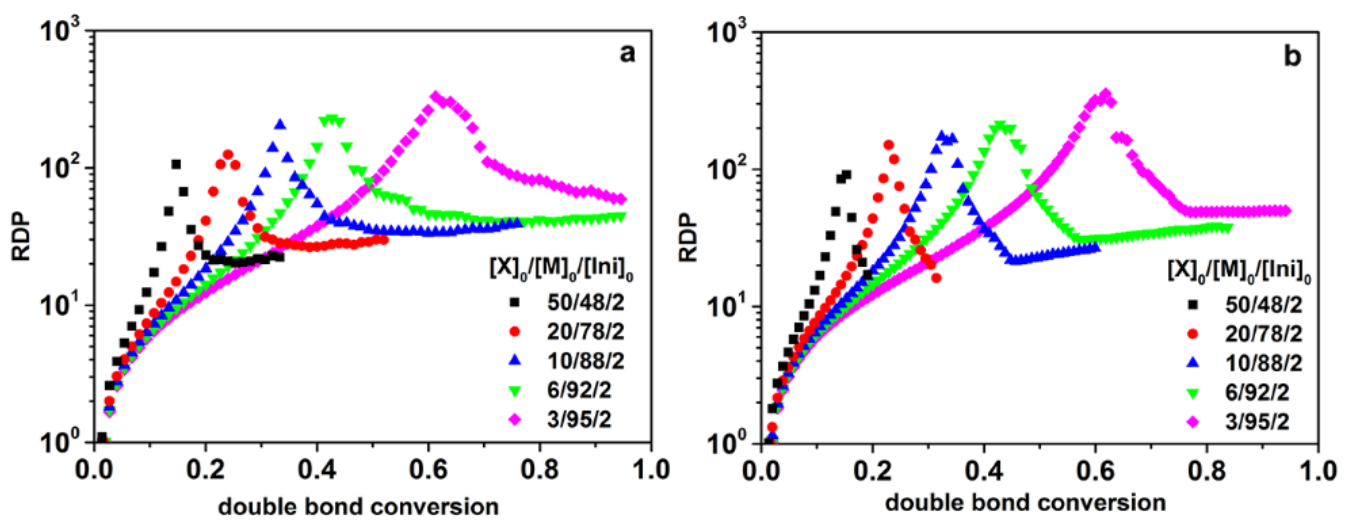

Figure S1. Simulation for ATRcP of monovinyl monomers and divinyl monomers.

The dependence of $R D P$ plotted vs. double bond conversion, obtained from (a) w.c. model and (b) wo.c. model for various $[\mathrm{X}]_{0} /[\mathrm{M}]_{0} /[\operatorname{Ini}]_{0}$.

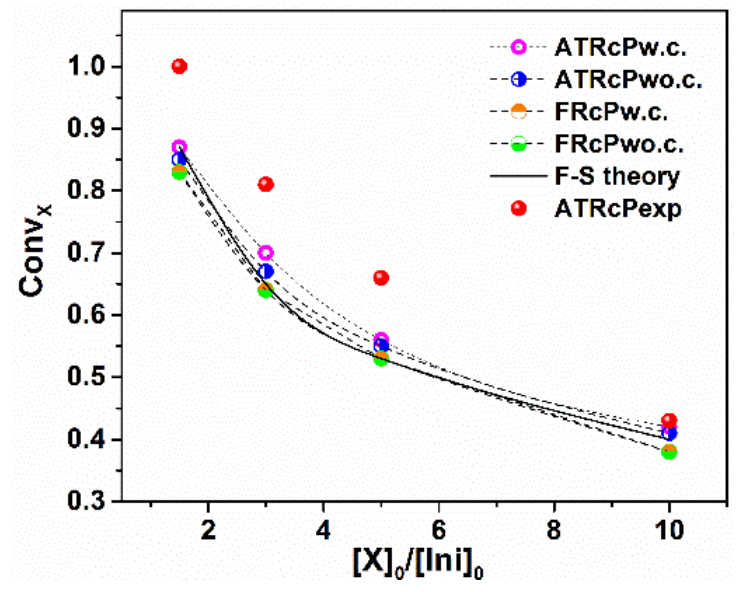

Figure S2. Comparison of the gel points $\left(C o n v_{\mathrm{x}}\right)$ for various initial molar ratios of divinyl monomer to initiator $[\mathrm{X}]_{0} /[\mathrm{Ini}]_{0}$, obtained from ATRcP, FRcP simulations and F-S theory. 

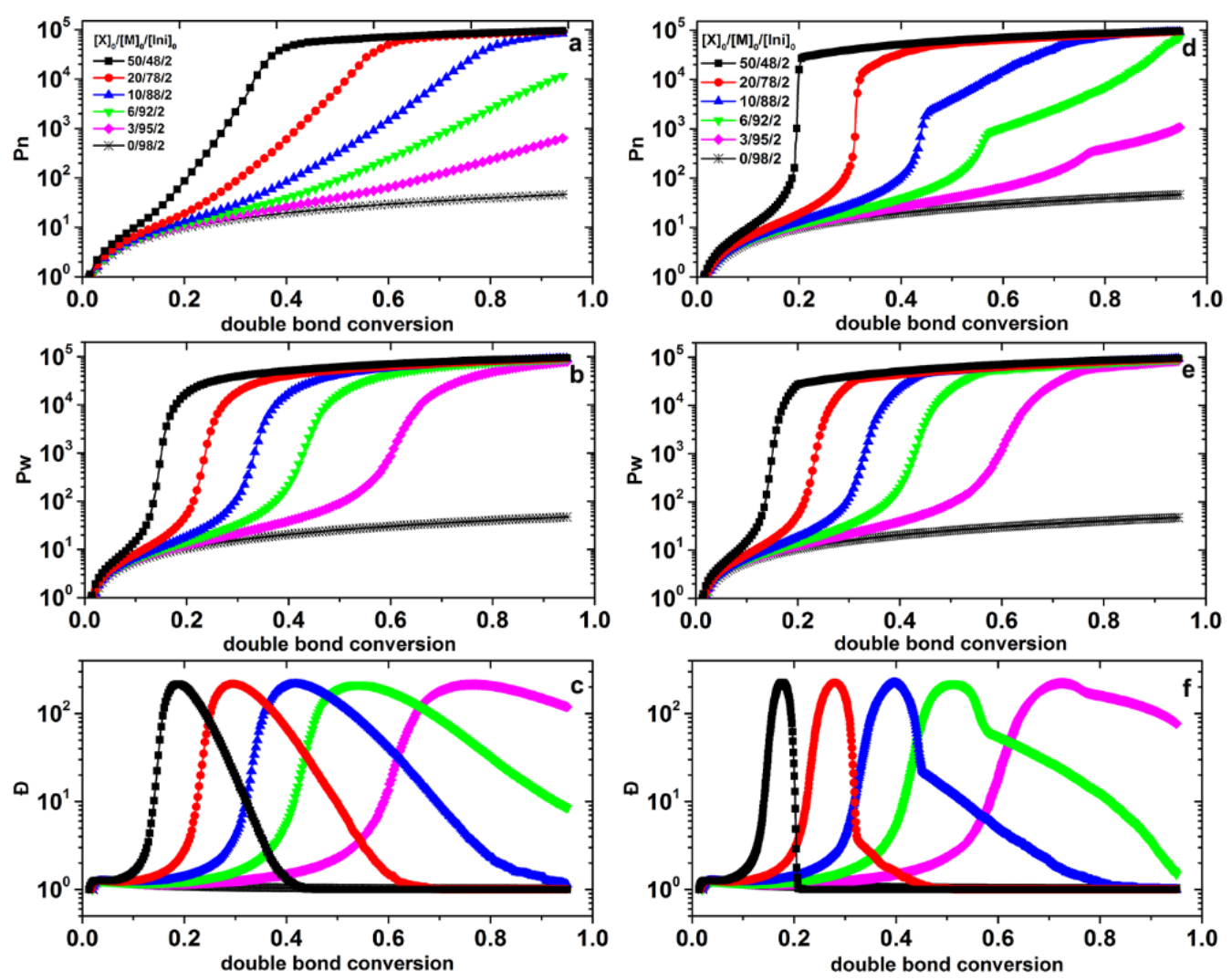

Figure S3. Simulation for ATRcP of monovinyl monomers and divinyl monomers.

The growth of $P_{\mathrm{n}}$ with double bond conversion for (a) w.c. model and (d) wo.c. model.

The growth of $P_{\mathrm{w}}$ with double bond conversion for (b) w.c. model and (e) wo.c. model. The growth of $Ð$ with double bond conversion for (c) w.c. model and (f) wo.c. model.

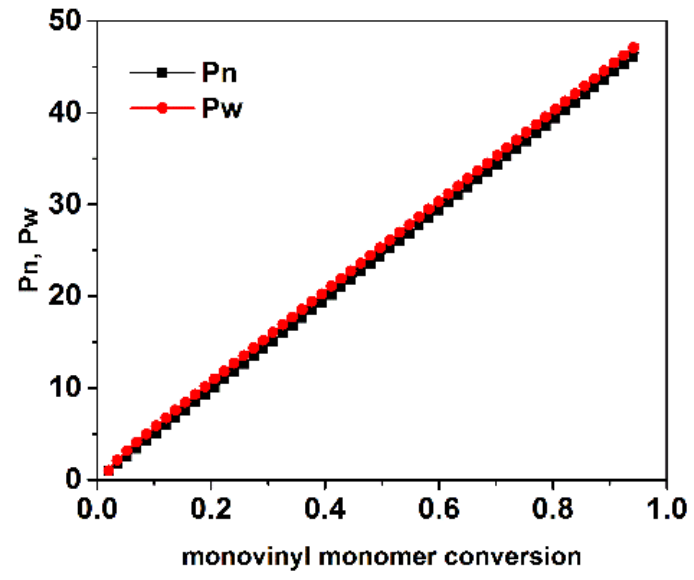


Figure S4. Simulation for ATRP of monovinyl monomers. The linear growth of $P_{\mathrm{n}}$ and $P_{\mathrm{w}}$ with monovinyl monomer conversion.

Table S1. Comparison of gel points of ATRcP of monovinyl and divinyl monomers obtained from experiments, F-S theory and different simulation models.

\begin{tabular}{|c|c|c|c|c|c|c|c|c|c|c|c|}
\hline \multirow{3}{*}{$\begin{array}{c}{[\mathrm{X}]_{0} /[\mathrm{M}]_{0} /[\mathrm{Ini}]_{0}} \\
20 / 78 / 2\end{array}$} & \multicolumn{2}{|c|}{ w.c. $\sin ^{\mathrm{a}}$} & \multicolumn{2}{|c|}{ wo.c. $\operatorname{sim}^{\mathrm{a}}$} & \multirow{2}{*}{$\begin{array}{c}\mathrm{ATRP}_{\exp }^{\mathrm{b}} \\
\text { Convx }\end{array}$} & \multicolumn{2}{|c|}{$\mathrm{F}-\mathrm{S}_{\text {calc }^{\mathrm{b}}}^{\mathrm{b}}$} & \multicolumn{2}{|c|}{ DLL w.c. ${ }^{b}$} & \multicolumn{2}{|c|}{ DLL wo.c. ${ }^{b}$} \\
\hline & Con & $\operatorname{Conv} \mathrm{X}_{\mathrm{X}}$ & Conv & Conv $v_{\mathrm{X}}$ & & Conv $v_{\mathrm{d}}$ & $\operatorname{onv} v_{\mathrm{X}}$ & Conv $v_{\mathrm{d}}$ & $n v \mathrm{x}$ & Con & Conv $\mathrm{x}$ \\
\hline & 0.24 & 0.42 & 0.23 & 0.41 & 0.43 & 0.22 & 0.40 & 0.38 & 0.57 & 0.34 & 0.55 \\
\hline $10 / 88 / 2$ & 0.33 & 0.56 & 0.32 & 0.55 & 0.66 & 0.32 & 0.53 & 0.50 & 0.71 & 0.46 & 0.68 \\
\hline $6 / 92 / 2$ & 0.44 & 0.70 & 0.43 & 0.67 & 0.81 & 0.41 & 0.65 & 0.62 & 0.83 & 0.56 & 0.78 \\
\hline $3 / 95 / 2$ & 0.64 & 0.87 & 0.62 & 0.85 & 1.0 & 0.58 & 0.82 & 0.83 & 0.95 & 0.76 & 0.90 \\
\hline
\end{tabular}

${ }^{\mathrm{a}}$ The values were calculated in this work. ${ }^{\mathrm{b}}$ The values for $\operatorname{Conv}_{\mathrm{x}}$ were taken from ref.

${ }^{[1,2]}$, and the values for $\operatorname{Conv}_{\mathrm{d}}$ were calculated in this work.

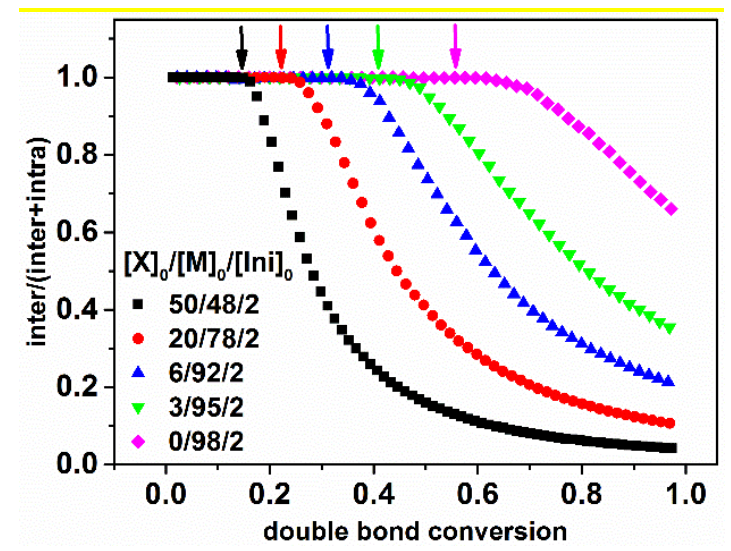

Figure S5. Simulation for ATRcP of monovinyl monomers and divinyl monomers using w.c. model shows the ratio of intermolecular crosslinking formed at different conversions. Ratio of intermolecular crosslinks per chain to all crosslinks per chain versus double bond conversion. Arrows indicate gel points. 


\section{Reference:}

(1) H. Gao, P. Polanowski, K. Matyjaszewski, Macromolecules 2009, 42, $5925-5932$.

(2) P. Polanowski, J. K. Jeszka, K. Krysiak, K. Matyjaszewski, Polym. (United Kingdom) 2015, 79, 171-178. 